\title{
DESCRIPTION OF TWO DIGENEAN PARASITES LECITHOCHIRIUM PRIACANTHI YAMAGUTI, 1953 (HEMIURIDAE) AND \\ PSEUDOPECOELOIDES ARTHERINOMORI AKEN'OVA ET AL, 2009 (OPECOELIDAE) INFECTING ANGUILLIDAE AND SERRANIDAE MARINE HOSTS IN EGYPT \\ By

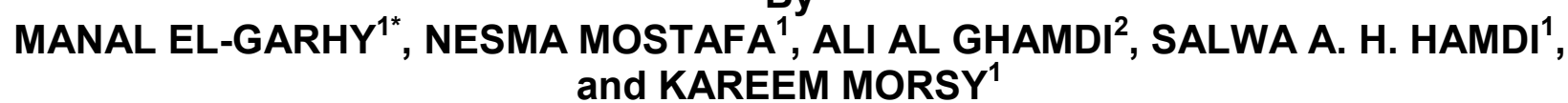 \\ Department of Zoology, Faculty of Science, Cairo University, Egypt and Department of Biology ${ }^{2}$, College of Science, Al Baha University, Saudi Arabia \\ ( ${ }^{*}$ Correspondence: manal_elgarhy@yahoo.com)
}

\begin{abstract}
The study described of two parasitic digenean species isolated from pyloric portion of stomach and middle part of their host intestines. Lecithochirium priacanthi Yamaguti, 1953 (Hemiuridae) \& Pseudopecoeloides artherinomori Aken'Ova et al, 2009 (Opecoelidae) respectively infecting two marine fish, the European sea eel Anguilla anguilla (Anguillidae) captured from Alexandria City coast, Mediterranean Sea and the spotted coral grouper Plectropomus maculatus (Serranidae) from coasts of Suez Gulf and Hurghada of the Red Sea, both species captured during the year 2015. The morphology and morphometric characterization were carried out by light microscopy. L. priacanthi characterized by elongated body measured $2.11 \pm 0.20 \mathrm{~mm}(1.93$ 2.54 ) in length with tapered conical anterior and cylindrical wide posterior ends, supplied with a very short retracted tail with blunt end and two large oval testes. This species is unique by two compact, lobed masses of vitellaria just posterior to ovary. $P$. artherinomori characterized by elongated slender body measured $1.8 \pm 0.02 \mathrm{~mm}$ (1.4-2.20) in length with a ventral sucker larger than oral sucker situated on a very short peduncle formed wrinkles around sucker. Both species were recorded for the first time from these host species in Egypt.
\end{abstract}

Key words: Lecithochirium priacanthi, Hemiuridae, Anguilla Anguilla, Pseudopecoeloides artherinomori, Opecoelidae, Plectropomus maculates, light microscopy.

\section{Introduction}

It is known that marine fish play important roles as intermediate or definitive hosts for a number of helminthes (Manter, 1940; Dogiel et al, 1964; Willams and Jones, 1994; Abdou et al, 2001). The digeneans of family Hemiuridae is commonest digeneans found inside digestive tract of marine fish, and the present isolated Lecithochirium is the most common genus of this family (Shih et al, 2004). Yamaguti (1971) gave diagnostic generic features of Lecithochirium are male gonads, fish host and harboring site in host (stomach and pyloric part of intestines) with testes being symmetrical, and immediately posterior to acetabulum. Surekha and Lakshmi (2005) reported that genus Lecithochirium has exclusive taxonomic characters like a well or poorly developed ecsoma and a presomatic pit, seminal vesicle bipartite or tripartite and occasionally coiled, vitellarium condensed and usually divided into 6-7 oval to digitiform lobes and with massive uterine coils. Genus Lecithochirium contains several species parasitic in marine fish such as: $L$. gravidum (Looss, 1907); L. physcon (Luhe, 1901); L. musculus (Looss, 1907); L. synodi Manter, 1931; L. furcolabiatum, (Luhe, 1901), L. conviva (Luhe, 1901); L. australis Manter, 1954; L. magnaporum Manter, 1940; L .genypteri (Manter, 1954); L. flexum (Manter, 1954) and L. trichiuri ( $\mathrm{Gu}$ and shen, 1981). The genus Lecithochirium now contains at least more than 100 species (Surekha and Lakshmi, 2005). This species was recorded in Coast of Yemen, the Red Sea. Lecithochirium sp. (Digenea: Hemiuridae) in the marine Fish Carangoides bajad by Al-Zubaidy (2010).

Opecoelidae (Ozaki, 1925) constitutes a large and cosmopolitan family of digeneans, which includes about 51 genera \& 465 
species (Yamaguti, 1971). Genus Pseudopecoeloides (Yamaguti, 1940) is a well established, contains elongate and slender worms with a pedunculated, non-papillate ventral sucker and an uroproct. All the nominal species confirmed to that concept, except Pseudopecoeloides equesi (Manter, 1947). $P$. equesi has five distinct papillae on ventral sucker and Manter (1947) suggested a new genus. Yamaguti (1971) gave ten Pseudopecoeloides, species but Bartoli et al. (2003) devised a key to 18 species. Seven species of Pseudopecoeloides including the present one were recorded from Australian temperate marine fishes (Aken'Ova et al, 2009) of five new species; P. hickmani, P. lesteri, P. arripi, P. atherinomori, P. hafeezullahi, P. scomberi (Hafeezullah, 1971) and P. tenuis (Yamaguti, 1940).

The present study described two parasites from two marine water different species.

\section{Materials and Methods}

A total of 83 marine fish samples of two different species, the European Sea eel Anguilla anguilla (Anguillidae) and Plectropomus maculatus (Serranidae) along Alexandria Governorate Mediterranean Sea coast, the Suez Gulf and Hurghada coasts of the Red Sea, respectively, over the year 2015. Samples were immediately transported in water tanks to the experimental laboratory and identified (Randall, 1983; Froese and Pauly, 2004). Fish were carefully dissected and examined for parasites, alimentary canal and internal organs were transferred to sterile normal saline in Petri dishes and stereomicroscopic examined. Digenetic trematodes were fixed and preserved (Cribb and Bray, 2010). Worms were stained with Carmine acetic acid, dehydrated in ascending series of ethanol and mounted on Canada balsam. Identification was done using standard keys (Yamaguti, 1971; Surekha and Lakshmi, 2005). Illustrations were done by a drawing tube, measurements in $\mathrm{mm}(\mathrm{M} \pm \mathrm{SE})$ with range in parentheses.

\section{Results}

Lecithochirium priacanthi Yamaguti, 1953
(Figs. 1, 2, 3,10a): 16/40 fishes (40\%) were naturally infected with digenetic trematode Lecithchirium priacanthi (Family: Hemiuridae0. Infection was recorded in stomach and mid intestinal wall of the European Sea eel Anguilla anguilla. Adult flattened, elongated with tapered conical anterior end and cylindrical posterior end at widest point measured $2.11 \pm 0.20 \mathrm{~mm}(1.93-2.54)$ x $0.67 \pm$ $0.02 \mathrm{~mm}$ (0.61-0.72). Body with short retracted ecsoma with blunt end measured $0.20 \pm$ $0.02 \mathrm{~mm}(0.18-0.25) \times 0.32 \pm 0.02 \mathrm{~mm}(0.28$ $0.35)$. Oral sucker: subterminal with a diameter of $0.10 \pm 0.03 \mathrm{~mm}(0.08-0.13)$ about $1 / 3$; ventral sucker $0.29 \pm 0.02 \mathrm{~mm} \quad(0.25$ 0.32 ) in diameter, at body posterior part of anterior third. Pharynx: $0.05 \pm 0.01 \mathrm{~mm}(0.03-$ 0.07 ) in length. Caeca wide, with a bifurcated tube terminated blindly posterior in front of tail base. Two large oval testes located laterally at body left median third part $0.16 \pm 0.03(0.13-0.21) \mathrm{mm}$ in diameter. Ovary: oval $0.22 \pm 0.03(0.19-0.26) \mathrm{mm} \mathrm{x}$ $0.15 \pm 0.02(0.13-0.21) \mathrm{mm}$, located at body posterior third end left of median line. Uterus was long, coiled, filled with eggs, not extended into posterior end with its main bulk between ovary and testes from acetabulum to end of intestinal caeca. Vitellaria: 2 compact masses located posterior to ovary.

Taxonomic summary:

Family: Hemiuridae Looss (1899).

Type species: Lecithochirium priacanthi Yamaguti (1953)

Type host: Europe eel Anguilla anguilla (F: Anguillidae Linnaeus, 1758)

Type locality: Mediterranean Sea Coasts of Alexandria Governorate, Egypt.

Type habitat and infection site: Adult worms attached to host's intestinal wall.

Prevalence: 16/40 fish species (40\%) naturally infected.

Etymology: Specific name derived from Priacanthus a genus host (Yamaguti, 1953).

Pseudopecoeloides atherinomori Aken' Ova et al. (2009) (Figs. 3-9, 10b,c): 27/43 fishes $(62.7 \%)$ were naturally infected with digenetic trematode Pseudopecoeloides ath- 
erinomori (F.: Opecoelidae). Infection in pyloric portion and mid-intestine of the spotted coral grouper Plectropomus maculates (F: Serranidae). Body: elongate, slender, measured $1.8 \pm 0.02 \mathrm{~mm}$ (1.4-2.20) in length, maximum width $0.2 \pm 0.02 \mathrm{~mm}(0.17-0.23)$ at gonads region. Oral sucker: subspherical, subterminal measured $0.15 \pm 0.02 \mathrm{~mm}(0.13$ $0.20)$ in diameter. Ventral sucker: spherical $0.25 \pm 0.02 \mathrm{~mm}(0.22-0.28)$ in diameter, larger than oral sucker and situated on a very short peduncle forming wrinkles around sucker. Fore body: short, $0.57 \pm 0.02 \mathrm{~mm}$ (0.53-0.64) in length. Pharynx: large, sub-spherical measured $0.08 \pm 0.02 \mathrm{~mm}(0.06-0.11)$ in length with numerous gland cells along posterior margin. Oesophagus: moderately long. Caeca: long, bifurcated opened into an excrettory vesicle close to posterior extremity forming uroproct. Testes: two circular, usually separate, occasionally contiguous (intand$\mathrm{em})$, at posterior body $0.15 \pm 0.02 \mathrm{~mm}(0.094-$ 0.16 ) in diameter, without cirrus-sac. Seminal vesicle: naked, long tubular, convoluted anteriorly, saccular posteriorly, extent from intestinal bifurcation to ventral sucker posteriorly. Genital atrium: doliiform with thick walled. Genital pore: submedian, anterior to intestinal bifurcation or slightly at pharynx posterior margin. Ovary: pre-testicular, sub-

Table 1: Comparative measurements $(\mathrm{mm})$ of present L. priacanthi isolated and those previously recorded (Yamaguti, 1953):

\begin{tabular}{|l|c|c|}
\hline Parasite & L. priacanthi (Yamaguti,1953) & Present L. priacanthi \\
\hline Host & Priacanthus hamrur & Anguilla anguilla \\
\hline Total body length & 2.3 & $2.11 \pm 0.20(1.93-2.54)$ \\
\hline Total body width & 0.68 & $0.67 \pm 0.02(0.61-0.72)$ \\
\hline Tail length & 0.525 & $0.20 \pm 0.02(0.18-0.25)$ \\
\hline Tail width & 0.35 & $0.32 \pm 0.02(0.28-0.35)$ \\
\hline Oral sucker diameter & 0.132 & $0.10 \pm 0.03(0.08-0.13$ \\
\hline Ventral sucker diameter & 0.4 & $0.29 \pm 0.02(0.25-0.32)$ \\
\hline Pharynx length & 0.075 & $0.05 \pm 0.01(0.03-0.07)$ \\
\hline Testes length & $0.18-0.2$ & $0.16 \pm 0.03(0.13-0.21)$ \\
\hline Ovary length & 0.15 & $0.22 \pm 0.03(0.19-0.26)$ \\
\hline Ovary width & 0.24 & $0.15 \pm 0.02(0.12-0.19)$ \\
\hline Vitellaria & seven elliptical masses & Two lobed masses \\
\hline
\end{tabular}

Table 2: Comparative measurements $(\mathrm{mm})$ of present $P$. atherinomori and two morphologically similar ones

\begin{tabular}{|l|c|c|c|}
\hline Variant & P. lesteri & P. atherinomori (Ova et al, 2009) & Present P. atherinomori \\
\hline Host & Pseudocaranx wrighti & Atherinomorus ogilbyi & Plectropomus maculates \\
\hline Total body length & $1.373-1.58$ & $1.312-2.155$ & $1.8 \pm 0.02(1.4-2.20)$ \\
\hline Total body width & $0.158-0.17$ & $0.146-0.194$ & $0.2 \pm 0.02(0.17-0.23)$ \\
\hline Oral sucker diameter & $0.085-0.095$ & $0.084-0.130$ & $0.15 \pm 0.02(0.13-0.20)$ \\
\hline Ventral sucker diameter & $0.105-0.107$ & $0.117-0.175$ & $0.25 \pm 0.02(0.22-.28)$ \\
\hline Pharynx length & $0.067-0.077$ & $0.062-0.084$ & $0.08 \pm 0.02(0.06-0.11)$ \\
\hline Testes & $0.136-0.147$ & $0.091-0.188$ & $0.15 \pm 0.02(0.094-0.16)$ \\
\hline Ovary length & $0.071-0.077$ & $0.075-0.143$ & $0.10 \pm 0.02(0.07-0.12)$ \\
\hline
\end{tabular}




\section{Discussion}

In the present study, Lecithochirium priacanthi Yamaguti, 1953 was commonest digeneans infecting the digestive tract of marine fishes, and present Lecithochirium sp. was also the commonest genus (Shih et al, 2004). Genus Lecithochirium is very unsatisfactory, with many variations and combination of characteristics difficult in identification (Manter, 1934). Yamaguti (1971) reported diagnostic generic features of Lecithochirium; male gonads, fish host and infected site. Surekha and Lakshmi (2005) stated that genus Lecithochirium have exclusive taxonomic characters as a well or poorly developed ecsoma and a presomatic pit or ventrocervical groove, seminal vesicle bipartite or tripartite and occasionally coiled. Vitellarium condensed and divided to 6-7 oval to digitiform lobes with massive uterine coils. The present species differed from Anguilla anguilla but shared distinctive characteristics of genus Lecithochirium Yamaguti (1953): elongated body, testes (one pair), vitellaria (two lobed masses instead of seven elliptical ones), uterus (coiled), and stomach infection site. The present species agreed with the species Lecithochirium priacanthi recovered from Priacanthus hamrur (Yamaguti, 1953), but the present species is distinguished from this species in the presence of reduced vitellaria as 2 compact masses and a short eversible tail (ecsoma) instead of 6-7 oval to digitiform vitellaria lobes. Another species $L$. grandiporum reported from Saurida tumbil along Egyptian Red Sea coast and differed from the present one in its papillated more larger ventral sucker and reversible longer ecosoma and multilobated digitiform vitellarium (Morsy et al, 2012). Measurements of the present $L$. priacanthi were slightly different than the comparable species that might be due to specimen preparation.

In the present study, Pseudopecoeloides atherinomori was described (Yamaguti, 1940). Aken'Ova et al. (2009) reviewed two species of Pseudopecoeloides and gave five new ones. They divided species into two groups (A \& B) on basis of the sucker ratio, Group A were those with the oral sucker larger than the ventral sucker and in Group B oral sucker was equivalent to or distinctly smaller than ventral one. Yamaguti (1970) stated that the relative positions of ovary and testes were consistent and useful in species identification, except in contracted samples. Post-testicular area has useful criteria. Madhavi (1975) and Bray (1987) also suffered in determining the relationship between the caeca and the excretory vesicle in a related species. The present species has an uroproct, based on observations on the single laterally mounted specimen. $P$. atherinomori can be accommodated in Group B, as resembled the species reported by Aken'Ova et al, (2009) in most morphometrical features except for shorter forebody and slightly longer posttesticular area relative to the body length. Anterior limit of the vitelline follicles in $P$. atherinomori is at about the level of the posterior margin of ventral sucker peduncle, whereas is about half-way between anterior margin of ovary and posterior margin of ventral sucker peduncle in $P$. lesteri. $P$. atherinomori and also possesses a vitelline distribution and in some metrical features.

\section{Conclusion}

Lecithochirium priacanthi and Pseudopecoeloides artherinomori are two digenean parasites isolated from two different marine fishes in Egypt, the European sea eel Anguilla anguilla and the spotted coral grouper Plectropomus maculates. The two species were compared with the parasites of the same genus isolated previously from different host species worldwide. Both species are recorded as new host and locality records in Egypt and further electron microscopy and molecular studies will be carried out as future studies to evaluate the exact taxonomic position of these species.

\section{Acknowledgement}

This work was kindly supported by Department of Zoology, Faculty of Science, Cairo University. 


\section{References}

Abdou, NL, Heckmann, RA, Beltagy, SM, Ashour, AA, 2001: Pseudoplagioporus interruptus Durio and Manter, 1968 and Hamacreadium agyptia sp. n. (Trematoda: Opecoeliidae) from the Red Sea fish in Egypt. J. KAU. Mar. Sci. 12:175-88.

Aken'Ova, O, Cribb, H, Bray, A, 2009: Seven species of Pseudopecoeloides Yamaguti, 1940 (Digenea, Opecoelidae) from temperate marine fishes of Australia, including five new species. Zoo-Keys. 5:1-32.

Al-Zubaidy, A, 2010: First record of Lecithochirium sp. (Digenea: Hemiuridae) in the marine fish Carangoides bajad from the Red Sea, coast of Yemen. J. KAU. Mar. Sci 21:85-94.

Bartoli, P, Bray, RA, Gibson, DI, 2003: Opecoelidae (Digenea) from western Mediterranean fishes: 3 rare species. Syst. Parasitol. 55:81-95.

Bray, RA, 1987: Some helminth parasites of marine fishes of South Africa: Family Opecoelidae (Digenea). J. Nat. History 21:1049-75.

Cribb, TH, Bray, RA, 2010: Gut wash, body soak, blender and heat fixation: approaches to the effective collection, fixation and preservation of trematodes of fishes. Sys. Parasitol.76:1-7.

Dogiel, VA, 1964: General parasitology. Oliver and Boyd, London.

Froese, R, Pauly, D, 2004: Fish Base. World Wide Web-Electronic Publication.

Hafeezullah, M, 1971: Opecoelid trematodes of marine fishes of India. Parasitol. 62:321-9.

Looss, A, 1907: Zur Kenntnis der Distomenfamilie Hemiuridae. Zool. Anz. 31:585-620.

Luhe, M, 1901: Uber Hemiuriden (Ein Beitrag zur Systematik der digenetischen Trematoden). Zool. Anz. 24:473-88.

Madhavi, R, 1975: Digenetic trematodes from marine fishes of Waltair Coast, Bay of Bengal. Family: Opecoelidae. Riv. Parassitol.36:153-64.

Manter, HW, 1931: Some digenetic trematodes of marine fishes of Beaufort, North Carolina.

Parasitol. 23:396-411.
Manter, HW, 1934: Some digenetic trematodes from deep water fishes of Tortugas Florida. Carnegie. Inst. Wash. Publ. 435:257-62.

Manter, HW, 1940: Digenetic trematodes of fishes from the Galapagos Islands and the neighboring Pacific. Allan Hancock Pacific Expeditions 2, 14:325-97.

Manter, HW, 1947: The digenetic trematodes of marine fishes of Tortugas, Florida. Am. Midland. Nat. 38:257-416.

Manter, HW, 1954: Some digenetic trematodes from fishes of New-Zealand. Trans. Roy. Soc. New Zealand. 82, 2:475-568.

Morsy, K, Bashtar, AR, Abdel-Ghaffar, F, Baksh, W, 2012: First record of Lecithochirium grandiporum (Digenea: Hemiuridae) infecting the lizard fish Saurida tumbil from the Red Sea. Parasitol. Res. 111, 6:2339-44.

Randall, JE, 1983: Red Sea reef fishes. London: IMMEl Publication Company.

Shih, HH, Liu, W, Zhao, ZQ, 2004: Digenean fauna in marine fishes from Taiwanese water with the description of a new species. Lecithochirium tetraorchis sp. nov. Zool. Stud. 43, 4: 671-6.

Surekha, P, Lakshmi CV, 2005: Lecithochirium testelobatus $\mathrm{n}$. $\mathrm{sp}$. (Digenea: Hemiuridae) from the lizard fish, Saurida undosquamis from Andhrapradesh Coast. J. Parasitol. Dis. 29, 2: 143-6.

Willams, H, Jones, A, 1994: Parasitic worms of fishes. Taylor and Francis, London.

Yamaguti, S, 1940: Studies on the helminth fauna of Japan, Part 31- Trematodes of fishes. Japn. J. Zool. 9:35-108.

Yamaguti, S, 1953: Parasitic worms mainly from Celebes: Part 3. Digenetic trematodes of fishes, II. Acta Med. Okayama 8:257-95.

Yamaguti, S, 1970: The digenetic trematodes of Hawaiian fishes. Tokyo: Keigaku Publishing Co. Yamaguti, S, 1971: Synopsis of Digenetic Trematodes of Vertebrates. 1. Tokyo: Keigaku Publishing Company.

\section{Explanation of figures}

Figs. 1\&2: Photomicrographs of Lecithochirium priacanthi infecting European sea eel Anguilla anguilla stained with Carmine, acetic acid (Schneider) showing elongated body pointed anteriorly and broad posteriorly terminated at a short ecsoma (EC). Subterminal oral sucker (OS), Pharynx (PH), Seminal vesicle (SV), Ventral sucker (VS), Ovary (O), Large coiled uterus (U), Seminal vesicle (SV), Two oval testes (TE), Lobed vitellaria (VT) and Intestinal caeca (IC).

Figs. 3-9: Photomicrographs of Pseudopecoeloides artherinomori infecting spotted coral grouper Plectropomus maculates stained with Carmine, acetic acid (Schneider). 3: Flattened adult worm with an anterior oral sucker (OS) followed by pharynx (PH). Body extends outside to wrinkle ventral sucker (VS) by a peduncle (PD). Vitellaria (VT) extends posteriorly from mid part of fore body, two spherical testes (TE) located at the posterior mid part of body. 4-9: High magnifications of: 4: Ventral sucker (VS) and surrounding peduncle (PD). 5-6: Anterior body region with subspherical oral sucker (OS), Pharynx (PH) and Oesophagus (OE). 7- Tubular seminal vesicle (SV), Eggs (E). 8- Mid region of body showing spherical testes (TE) and Operculated eggs (E). 9- Worms' eggs (E). 
Fig.10: Line diagrams of (a): Lecithochirium priacanthi. Scale bar, $0.063 \mathrm{~mm}$ (b) Ventral view, Scale bar, $0.11 \mathrm{~mm}$ (c) lateral view (Scale bar, 0.11 $\mathrm{mm}$ ) of Pseudopecoeloides artherinomori. Oral sucker (OS), Ventral sucker (VS), Pharynx (PH), Intestinal caeca (IC), Testes (TE), Ovary (OV), Ductus hermaphroditicus (DH), Terminal genitalia (TG), Genital pore (GP), Eggs (E), Uroproct (UP), Seminal vesicle (SV), Vitellaria (VT).

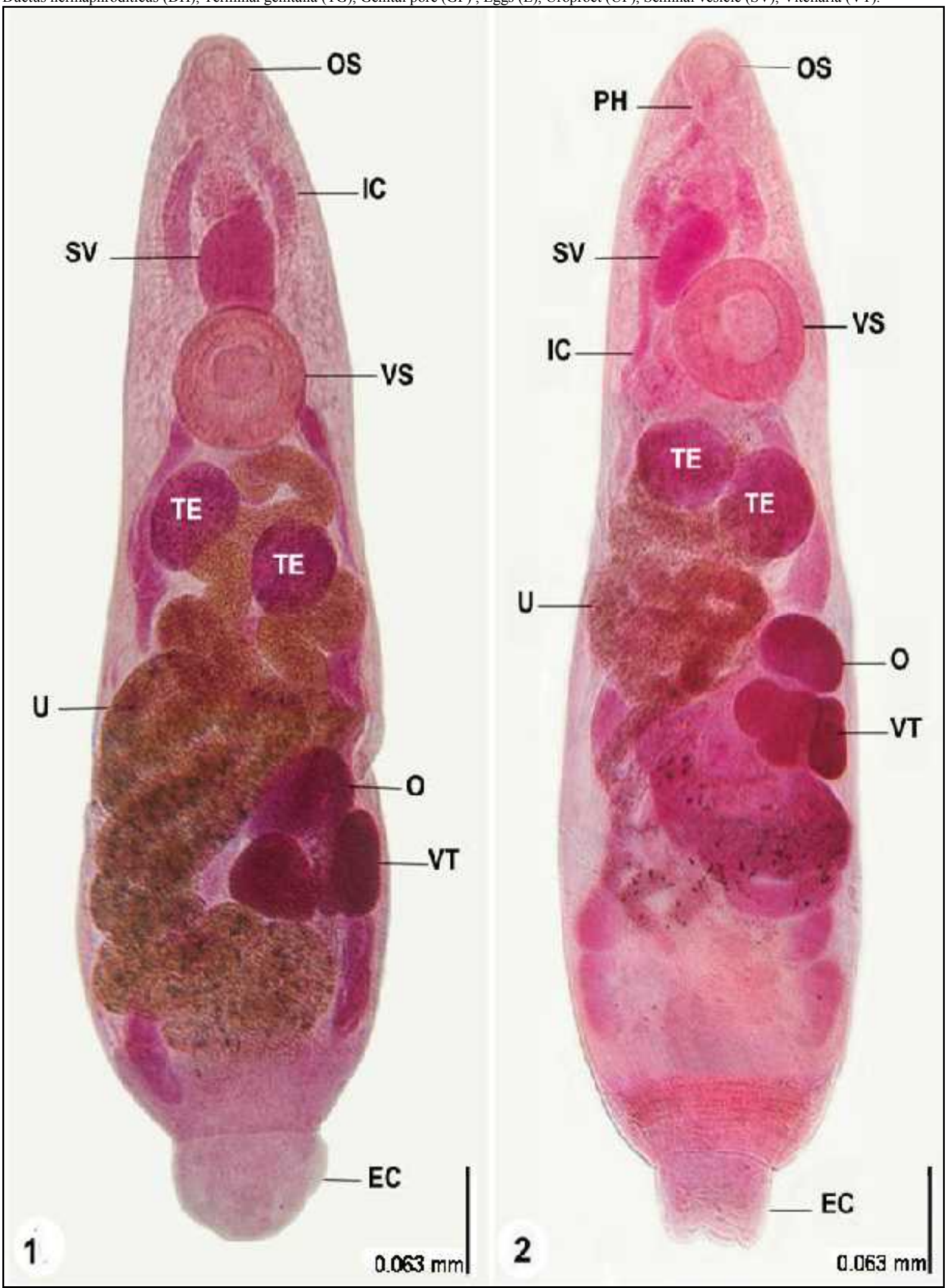




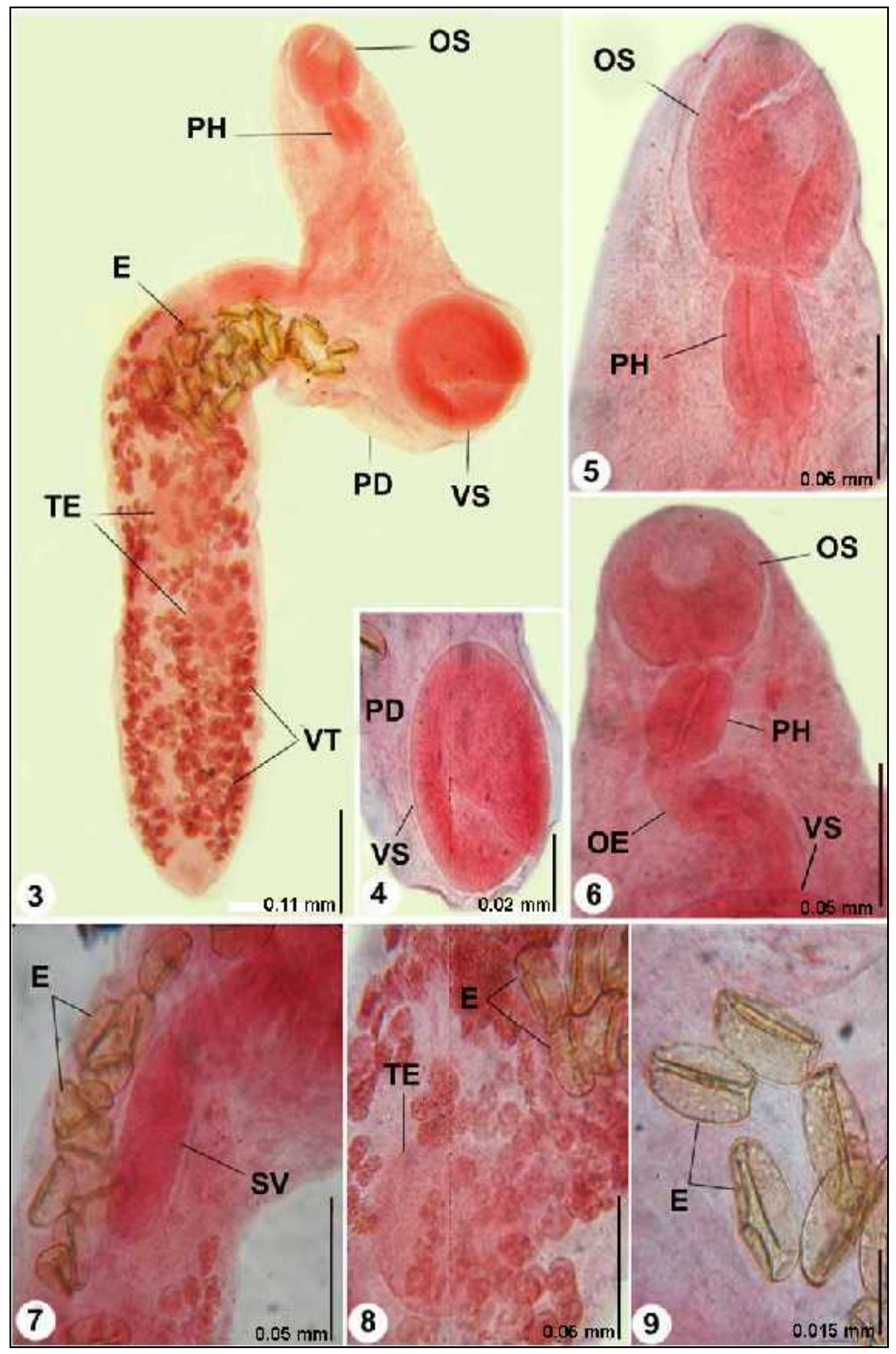




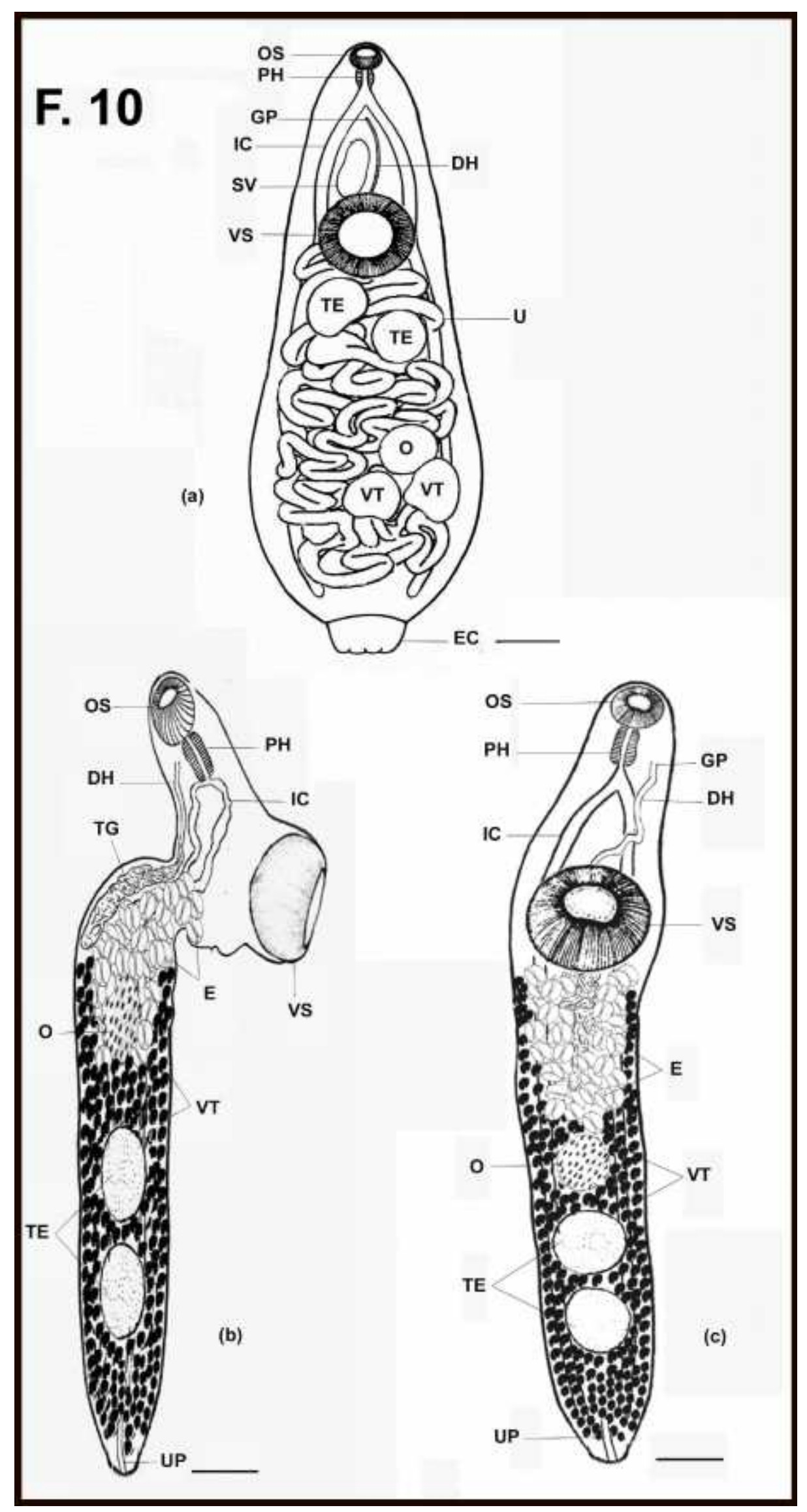

